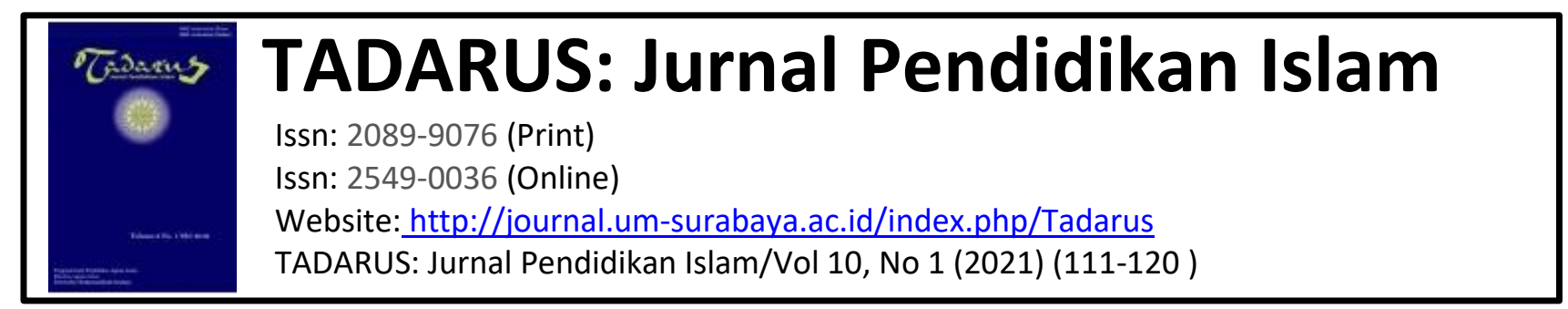

\title{
PENGEMBANGAN MEDIA PEMBELAJARAN BERBASIS APLIKASI ANDROID PADA MATA PELAJARAN SEJARAH KEBUDAYAAN ISLAM
}

\author{
Rizqy Rizal Fanani ${ }^{1}$, Achmad patoni ${ }^{2}$, Adi Wijayanto ${ }^{3}$ \\ IAIN TULUNGAGUNG \\ Rizqyrizalfanani98@gmail.com ${ }^{1}, \underline{\text { Patoni_Achmad@yahoo.co.id }}{ }^{2}, \underline{\text { Wijayantoadi@yahoo.com }}{ }^{2}$
}

\begin{abstract}
ABSTRAK
Dilatarbelakangi oleh rendahnya penggunaan media pembelajaran oleh guru pada materi Isra' Mi'raj di MIN 7 Tulungagung maka penelitian ini bertujuan untuk merancang media pembelajaran berupa aplikasi berbasis android. Penelitian dan pengembangan ini bertujuan untuk : (1)menghasilkan produk media pembelajaran berbasis aplikasi android mata pelajaran sejarah kebudayaan Islam. (2) mengetahui produk valid dan keefektifan media pembelajaran berbasis aplikasi android. Jenis penelitian yang digunakan adalah penelitian dan pengembangan model 4-D oleh Thiagarajan. Prosedur pengembangan produk terdapat 4 tahap yaitu define (pendefinisian), design (perancangan), development (pengembangan), disseminate (penyebaran). Penelitian dan pengembangan menunjukkan hasil sebagai berikut. (1) Produk berupa media pembelajaran berbasis aplikasi android mata pelajaran sejarah kebudayaan Islam menggunakan Coreldraw, Kinemaster, smart apps creator sebagai aplikasi pembuat aplikasi android, dan Lexis audio editor sebagai editing audio (suara). Produk media berbasis webseries telah dinyatakan layak sebagai media pembelajaran berdasarkan validasi ahli materi dengan presentase $87 \%, 93,7 \%$ dan $92,1 \%$ dengan kriteria sangat layak, ahli media diperoleh rata-rata presentase nilai 87,5\%, 89,1\% dan $83,6 \%$ dengan kriteria "layak". (2) Keefektifan produk media untuk mata pelajaran sejarah kebudayaan Islam berbasis aplikasi android diperolah dari meningkatnya hasil belajar peserta didik.
\end{abstract}

Katakunci : Media Pembelajaran, Aplikasi Android, Sejarah Kebudayaan Islam

\section{A. Pendahuluan}

Perkembangan Teknologi Informasi dan Komunikasi (TIK) yang sangat pesat telah berpengaruh di berbagai bidang kehidupan masyarakat apa lagi untuk generasi milenial. Generasi saat ini lebih sering membawa gadget dari pada membawa buku dalam kegiatan belajar. Hal tersebut menjadi salah satu hal yang mendasari kurangnya minat baca orang indonesia yang saat ini bukan menjadi rahasia lagi. Belajar adalah proses menerima pesan atau kegiatan dalam rangka memperoleh informasi dari 
berbagai sumber. ${ }^{1}$ Kegiatan belajar yang dalakukan bertujuan untuk untuk mempelajari suatu hal dari pengalaman yang diperoleh dari sumber tersebut. belajar dapat dilaksanakan dimana saja dan kapan saja asalkan seseorang yang belajar memperoleh kenyaman saat belajar.

Pada umumnya belajar kegiatan belajar formal berada disekolah. Tapi, belajar diera digital seperti ini tidak harus terpaku pada media cetak (buku). Belajar bisa dilakukan dengan cara home schooling (belajar dirumah) dengan cara membaca e-book (buku elektonik. Belajar dengan buku eletronik lebih ringkas dan ringan dikarena dapat diakses dengan mudah melalui gawai yang dimiliki oleh seseorang tidak terkecuali seorang peserta didik. ${ }^{2}$ Kegiatan tersebut terjadi karena pengaruh dari kemajuan ilmu pengetahuan dan teknologi, sehingga memudahkan mobilitas manusia dalam menentukan pilihan.

Belajar dengan cara membaca buku dalam beberapa kurun waktu terakhir mengalami penurunan. Penurunan tersebut harus disisasati oleh seorang guru, Dalam hal ini guru memiliki tantangan besar untuk memanfaatkan kecanggihan Teknologi Informasi dan Komunikasi sebagai alat atau media untuk memajukan pendidikan di era globalilisasi. Abad ke-21 Pesatnya perkembangan teknologi dan informasi menuntut guru untuk menyesuaikan diri dengan mampu menguasai IT untuk dapat diterapkan dalam perencanaan maupun proses pembelajaran berlangsung. ${ }^{3}$ Penguasaan Teknologi tersebut dapat dimanfaatkan guru untuk media pembelajaran yang nantinya memudahkan guru dalam menyampaikan materi pembelajaran. Terlebih saat pandemi seperti ini yang mengharuskan guru untuk menggunakan teknologi sebagai media agar pembelajaran terselamatkan dan bisa tetap berlangsung.

Era digital seperti saat ini perkembangan teknologi dan proses pembelajaran sudah saatnya pada saat ini bersinergi. penggunaan teknologi sebagai media dalam proses pembelajaran sebagai upaya dalam menggali potensi sumber belajar

\footnotetext{
${ }^{1}$ Rifki Afandi, Pengembangan Media Pembelajaran Permainan Ular Tangga untuk Meningkatkan Motivasi Belajar Siswa dan Hasil Belajar IPS di Sekolah Dasar. JINop (Jurnal Inovasi Pembelajaran) Vol 1, No 1, 2015.

${ }^{2}$ Rusman, Belajar dan Pembelajaran Berbasis Komputer. (Bandung: Alfabeta, 2018)

${ }^{3}$ Fitia Nur Rohmah \& Imam Buchori, Pengembangan Media Pembelajaran Interaktif Mata Pelajaran Korespondensi Berbasis Android Menggunakan Articulate Storyline. Economic \& Education Jurnal Vol 2, No 2, 2020
} 
memberikan kontribusi yang positif dalam pemebelajaran. Selain itu, menurut Purwanto dalam Bukori memanfaatkan teknologi sebagai media menyampaikan materi pembelajaran kepada peserta didik harapanya agar mempermudah peserta didik dalam menerima materi pembelajaran sehingga lebih efektif dan efisien. ${ }^{4}$ Dengan begitu tugas guru akan lebih ringan dan akhirnya dapat meningkatkan level pembelajaran Namun, banyak guru yang belum memaksimalkan penggunaan media dalam proses pembelajaran yang dilakukan. Guru masih banyak menggunakan metode pembelajaran secara konvensional, yaitu dengan metode ceramah dan pemberian tugas. Dikarenakan penggunaan media pembelajaran berbasis teknologi masih dianggap sukar oleh sebagian tenaga pendidik karena kesulitan pengoperasian, mahalnya biaya pembuatan dan kesulitan dalam memilih media yang sesuai atau serasi dengan mata pelajaran.

Mata pelajaran Sejarah Kebudayaan Islam (SKI) merupakan Salah satu contoh mata pelajaran yang selama ini diberikan dengan metode ceramah dan pemberian tugas. Karena, mata pelajaran sejarah kebudayaan Islam memiliki karakter materi dengan cakupan luas, terdiri atas bab sampai sub-bab. Menurut data empiris yang didapatkan selama ini melalui observasi yang dilakukan peneliti di MIN 7 Tulungagung. Peneliti mendapati peserta didik kurang memberikan minat dan perhatian seksama pada mata pelajaran sejarah tersebut. hal tersebut terjadi karena pendidik belum mengembangkan media. Padahal Sejarah Kebudayaan islam merupakan salah satu mata pelajaran penting dalam kurikulum Pendidikan Agama Islam.

Penggunaan media mampu membantu siswa memahami materi yang dirasa dirasa sulit dimengerti. ${ }^{5}$ Karena dengan menggunakan media pembelajaran proses komunikasi dan interaksi antara peserta didik dengan pendidik akan lebih cepat diterima. Selain mempercepat proses interaksi penyampaian materi, media pembelajaran juga menjadi alat untuk menghindari kejenuhan, memotivasi minat belajar siswa seta meningkatkan hasil belajar siswa.

\footnotetext{
4 Ahmad Buchori, Pengembangan Multimedia Interaktif Dengan Pendekatan Kontekstual Untuk Meningkatkan Pemecahan Masalah Kemampuan Matematika, Jurnal Inovasi Teknologi Pendidikan, Vol 6, No 1, 2019.

5 Syaiful Bahri Djamarah dan Aswan Zain, Strategi Belajar Mengajar (Jakarta:Penerbit Rinek Cipta,2012)
} 
Pengembangan media pembelajaran berbasis aplikasi android bisa menjadi solusi bagi pembelajaran SKI agar pembelajaran bisa menyenangkan. Aplikasi yang dibungkus dengan berbagi warna dan desain yang menarik, akan mudah dipahami dan diserap oleh siswa. Media pembelajaran yang dikembangkan sesuai dengan perkembangan teknologi, situasi dan sarana prasarana yang terdapat dilembaga pendidikan. Pengembangan media ini dapat digunakan secara offline dengan smartphone android. Materi dalam penegembangan media ini mengacu pada kurikulum K13 dan dibuat berdasarkan kebutuhan peserta didik serta lembaga pendidikan atau sekolah untuk melakukan peningkatan kualitas pembelajaran.

Penelitian ini bertujuan untuk mengembangkan media pembelajaran berbasis aplikasi android pada mata pelajaran Sejarah Kebudayaan islam (SKI). Analisis kelayakan dari media pembelajaran yang dikembangkan dilakukan sebelum uji secara terbatas untuk melihat kontribusi media pembelajaran berbasis aplikasi android dalam meningkatkan hasil belajar peserta.

\section{B. Metode Penelitian}

Jenis yang digunakan dalam penelitian ini adalah metode penelitian dan pengembangan atau Reseacrh and Development. Metode penelitian dan pengembangan atau Reseacrh and Development adalah metode penelitian yang digunakan untuk menghasilkan produk tertentu dan menguji keefektifan produk tersebut. ${ }^{6}$ Untuk menghasilkan produk tertentu diperlukan analisis kebutuhan untuk menguji keefektifan produk tersebut, supaya dapat berfungsi di masyarakat luas, maka diperlukan penelitian untuk menguji keefektifan produk tersebut.

Produk yang dikembangkan dalam pengembangan adalah media pembelajaran berupa Aplikasi android mata pelajaran sejarah kebudayaan Islam kelas IV di MIN 7Tulungagung. Estimasi waktu yang digunakan untuk penelitian mulai bulan Mei-juni 2021.

Model penelitian dan pengembangan ini mengacu pada modifikasi yang dikembangkan oleh Thigarajan yang biasa dissebut 4D. Menurut Sugiyono Model 4-D terdiri dari (1) define (pendefinisian) merupakan tahap untuk menetapkan dan

\footnotetext{
${ }^{6}$ Sugiyono, Metode Penelitian Kuantitatif, Kualitatif, dan R\&D (Bandung: CV. Alfabeta, 2011)
} 
mendefinisikan syarat syarat yang harus dipenuhi dalam pengembangan pembelajaran; (2) design (perancangan) Rancangan media pembelajaran dalam pengembangan ini meliputi pembuatan story board, penataan materi dalam media (layout), pembuatan skenario pembelajaran, penyusunan materi dan pembuatan latihan soal yang divisualisasikan pada media yang dikembangkan; (3) development (pengembangan) yaitu pengembangan dilakukan validasi serta review oleh ahli yang kemudian diuji cobakan kepada peserta didik; (4) disseminate (penyebaran) yaitu yaitu tahap penyebaran yang bertujuan untuk menyebarluaskan media yang selesai dikembangkan. ${ }^{7}$

Desain uji coba dalam penelitian ini menerapkan One Group Pretest-posttest Design yaitu desain uji coba yang mana sebelum dilakukan uji coba akan diberikan Pretest terlebih dahulu dan setelah uji coba diberikan posttest dengan tujuan untuk melihat perbedaan hasil belajar peserta didik sebelum dan sesudah menggunakan media pembelajaran. ${ }^{8}$

Subyek atau sasaran penelitian adalah siswa kelas IV di MIN 7 Tulungagung sebanyak 27 siswa. Menurut Sadiman, Rahardjo, Haryono, \& Harjito dalam penelitian pengembangan perlu diuji cobakan kepada 10 sampai 20 peserta didik saja dengan beberapa pertimbangan termasuk efisiensi. ${ }^{9}$ Validasi produk dilakukan oleh validator ahli media pembejaran sebanyak 3 orang, dosen dan ahli teknologi informasi serta ahli materi sebanyak 3 orang yaitu dosen dan guru mata pelajaran sejarah kebudayaan Islam.

Data yang digunakan data kuantitatif deskriptif. Data kuantitatif deskriptif ini digunakan untuk mendeskripsikan hasil validasi para ahli media dan ahli materi SKI, yang berupa hasil pengisian angket untuk menilai media pembelajaran yang dikembangkan peneliti sebelum diimplementasikan di kelas. Data yang telah diperoleh nantinya diolah sehingga diperoleh gambaran mengenai kelayakan media pembelajaran berbasis aplikasi android, efektivitas media dan peningkatan hasil belajar peserta didik setelah menggunakan media berbasis aplikasi android.

\footnotetext{
${ }^{7}$ Sugiyono, Metode Penelitian Kuantitatif, Kualitatif, dan R\&D, (Bandung : Alfabeta, 2015)

${ }^{8}$ Ali Maksum, Metodologi Penelitian dalam Olahraga. (Surabaya: FIK Unesa Press, 2008)

${ }^{9}$ A Sadiman Dkk, Media Pedidikan (Jakarta: PT RajaGrafindo Persada, 2009)
} 
Instrumen pengumpulan data yang digunakan untuk mendapatkan data penelitian ini terdiri atas angket validasi produk dan tes atau uji kompetensi hasil belajar. Tes berupa soal dengan bentuk pilihan ganda atau pilihan ganda sebanyak 20 soal. Instrumen tes divalidasi oleh ahli materi dan ahli media Validasi instrumen dilakukan expert judgment ahli media dan ahli materi. Hal tersebut dilakukan dengan tujuan mendapatkan kualitas intrumen yang baik dan benar. Aspek penilaian telaah ahli media dan materi meliputi : aspek materi, aspek pembelajaran, aspek pengoprasian program dan aspek tampilan.

Selanjutnya validasi instrumen dilakukan melalui konsultasi dengan ahli media dan ahli materi baik dosen, guru pengampu mata pelajaran, dan ahli teknologi informasi. Selanjutnya data yang diperoleh dari angket dan saran atau komentar yang diperoleh dari ahli materi dan media dianalisis untuk memperbaiki media berbasis aplikasi android mata pelajaran sejarah kebudayaan Islam. Data yang diperoleh dari validasi ahli materi dan media dianalisis atau dihitung dengan rumus sebagai berikut :

$$
\text { Hasil }=\frac{\text { skor } \text { yang diperoleh }}{\text { skor maksimum }} \times 100 \%
$$

Kemudian hasil dikonversikan sesuai dengan kategori kriteria analisis kelayakan media. ${ }^{10}$ Sebagaimana terlampir pada Tabel 1.

Tabel 1 Kriteria Kelayakan Media

\begin{tabular}{|l|l|l|}
\hline No & Skor dalam persen (\%) & Kategori Kelayakan \\
\hline 1 & $<21 \%$ & Sangat Tidak Layak \\
\hline 2 & $21-40 \%$ & Tidak Layak \\
\hline 3 & $41-60 \%$ & Cukup Layak \\
\hline 4 & $61-80 \%$ & Layak \\
\hline 5 & $81-100 \%$ & Sangat Layak \\
\hline
\end{tabular}

Selain itu,hasil perolehan data dari soal Pre-test dan Post-test kemudian dianalisis menggunakan analisis gain score dan uji t dengan tujuan untuk mengetahui apakah terdapat peningkatan pemahaman peserta didik.

\section{Hasil Penelitian Dan Pembahasan}

Tahap pertama dalam pengembangan ini adalah tahap analisi kebutuhan. Berdasarkan observasi dan wawancara yang telah dilaksanakan, peneliti mendapat

\footnotetext{
${ }^{10}$ Suharsimi Arikunto, Prosedur Penelitian Suatu Pendekatan Praktik. (Jakarta: Rineka Cipta.2012)
} 
informasi bahwa setiap guru menggunakan media pembelajaran dalam setiap melakukan kegiatan pembelajaran dengan tujuan agar materi yang disampaikan ke peserta didik dapat diterima dengan baik. Dengan adanya pengembangan multimedia interaktif berbasis aplikasi android, maka diharapkan agar peserta didik menjadi lebih tertarik dalam mempelajari materi Isra' Mi'raj dalam pembelajaran SKI. Hal tersebut dikarenakan bahwa media pembelajaran aaplikasi android belum pernah digunakan di MIN 7 Tulungagung (Hasil wawancara).

Minimnya media pembelajaran di MIN 7 Tulunngagung membuat peserta didik memiliki anggapan bahwa mempelajari materi SKI Isra' Mi'raj membosankan, yang berakibat pada peserta didik sudah merasa pesimis untuk dapat menguasai materi Isra' Mi'raj. Dikarenakan beberapa faktor tersebut yang dianggap peneliti cukup fatal, maka peneliti melakukan suatu upaya untuk melakukan pengembangan terhadap salah satu media pembelajaran yang dirasa dapat membantu masalah yang sedang dihadapi. Pengembangan berbasis aplikasi android diharapkan dapat membantu guru dalam meningkatkan pemahaman dan hasil belajar peserta didik. Selain itu juga dapat memberikan bantuan kepada peserta didik untuk dapat belajar materi Isra' Mi'raj secara mandiri karena media ini dapat diakses secara individu.

Berdasarkan hasil analisis kebtuhan lapangan, peneliti mengumpulkan beberapa referensi yang barkaitan dengan produk yang akan dikembangkan. Peneliti terlebih dahulu menentukan Kompetensi Inti, Kompetensi Dasar, Indikator, dan materi sesuai dengan kurikulum 2013 pada mata pelajaran SKI. Langkah selanjutnya yaitu untuk Menyusun RPP, media pembelajaran yang baik, dan disesuaikan dengan karakteristik peserta didik usia SD/MI. Selain itu, peneliti juga akan Menyusun instrument penelitian yang berupa angket validasi untuk ahli media dan ahli materi, serta angket validasi pretest posttest untuk ahli bidang tersebut. Hasil define (pendefinisian) mata pelajaran sejarah kebudayaan Islam materi Isra' Mi'raj, diperoleh dari data interview dan rencana pelaksanaan pembelajaran yang akan digunakan sebagai pedoman pengembangan media pembelajaran. Media pembelajaran yang dikembangkan memuat materi Isra' Mi'raj.

Setelah mendapatkan bahan untuk membuat media dari tahap yang pertama yaitu define (pendefinisian), peneliti melakukan perancangan media pembelajaran berbasis aplikasi android dan melakukan diskusi dengan dosen pembimbing, kepala TADARUS: Jurnal Pendidikan Islam/Vol 10, No 1 (2021) 
madrasah, dan guru mata pelajaran SKI MIN 7 Tulungagung. Adapun hasil diskusi tersebut pada tahap ini yaitu RPP dan storyboard. Produk yang dihasilkan adalah berupa media berbasis aplikasi android untuk meningkatkan hasil belajar SKI peserta didik kelas IV MIN 7 Tulungagung.

Selanjutnya hasil pengembangan produk media pembelajaran sejarah kebudayaan Islam kelas IV MIN 7 Tulungagung berhasil dikembangkan dengan bantuan Coreldraw, Kinemaster, smart apps creator sebagai aplikasi pembuat aplikasi android, dan Lexis audio editor sebagai editing audio (suara). Pengguna dapat mengakses media ini melalui share lewat whatsapps maupun alat sahre lainya. Berikut tampilan media pembelajaran berbasis aplikasi android yang dapat dilihat pada gambar tampian hasil pengembangan.

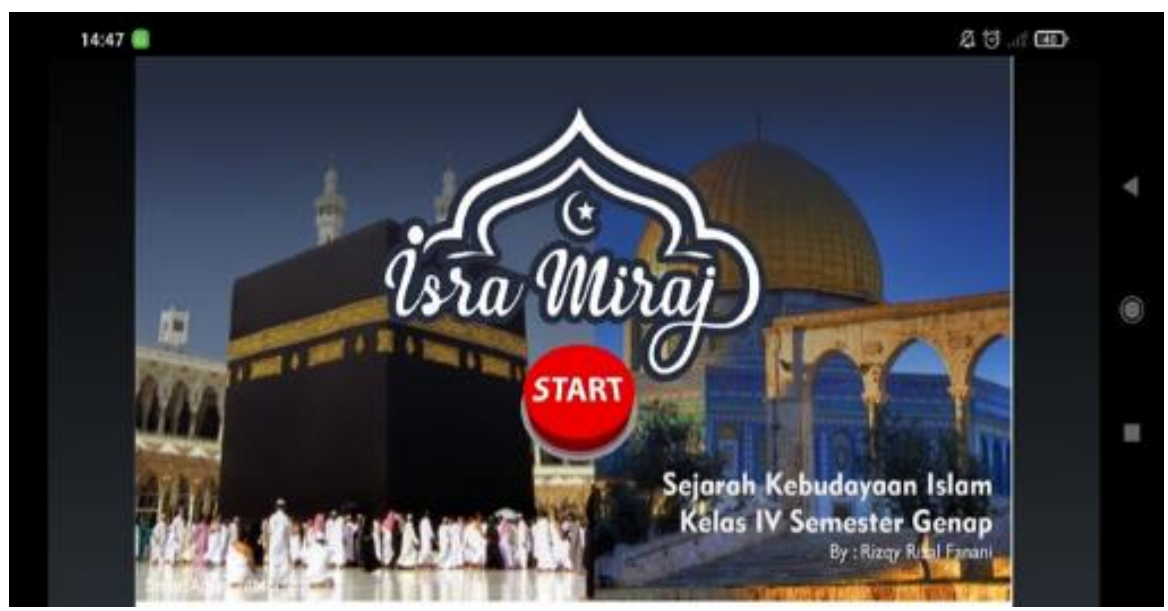

Gambar 1. Halaman awal

Pada scene intro atau halaman awal terdapat judul, nama kreator, logo, animansi gambar masjidil haram dan ka'bah, tobol start, serta tulisan kelas IV semester genap yang menunjukkan bahwa modul ini digunakan untuk MI kelas IV. Intro dibuat menarik agar menarik siswa agar tertarik untuk membukanya dan mempelajarinya. Setelah menu ini ada bagian daftar menu sebagimana terlihat pada gambar 2 


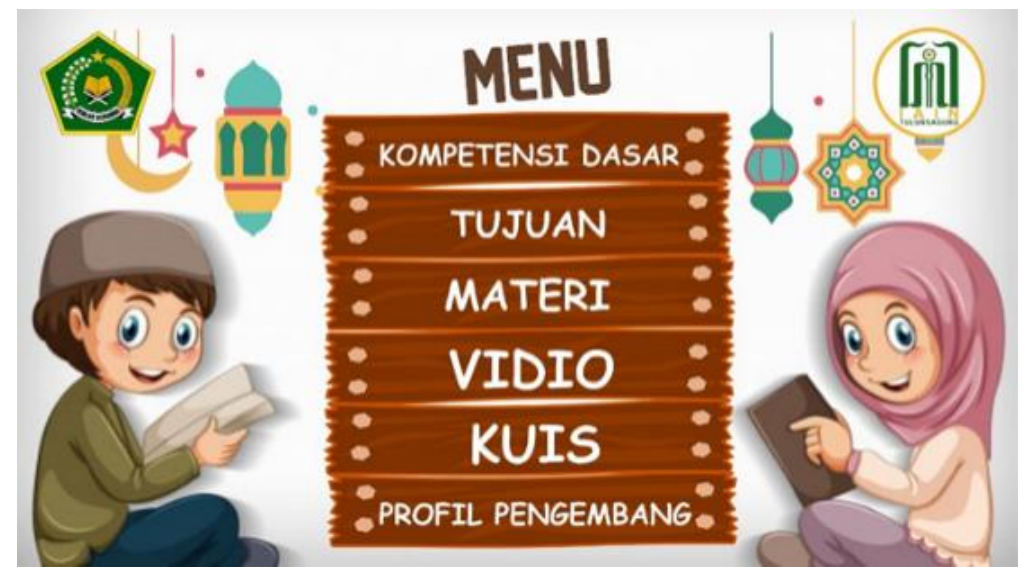

Gambar 2. Halaman Menu

Pada main menu ini terdapat judul dan beberapa tombol pilihan yang isinya mengarah pada pilihan diantaranya kompetensi dasar, tujuan, materi, vidio, kuis, profil pengembang.

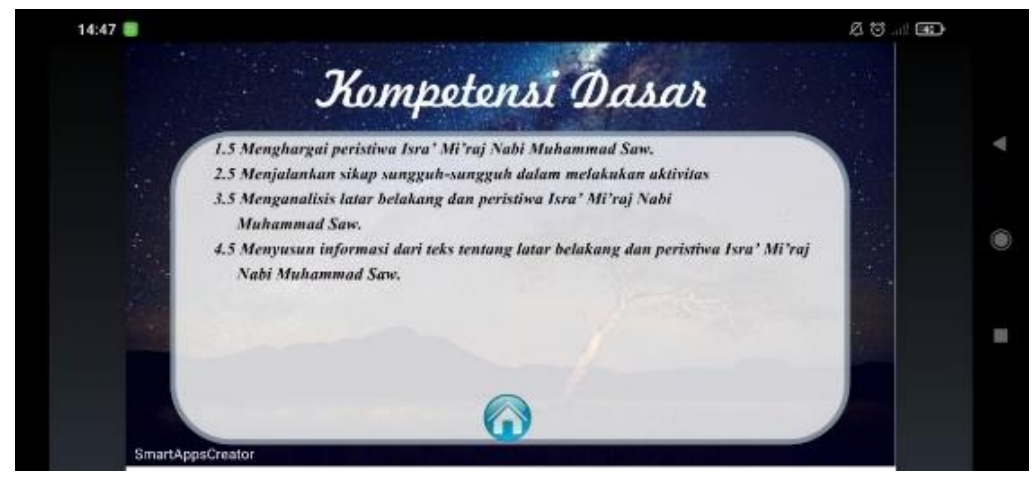

Gambar 3. Halaman KD

Pada scene KD ini disuguhkan kompetensi dasar sesuai dengan Buku dari kemenag. Kompetensi dasar ini bertujuan untuk menunjukan apa yang harus dicapai siswa selama pembelajaran pada menu ini.

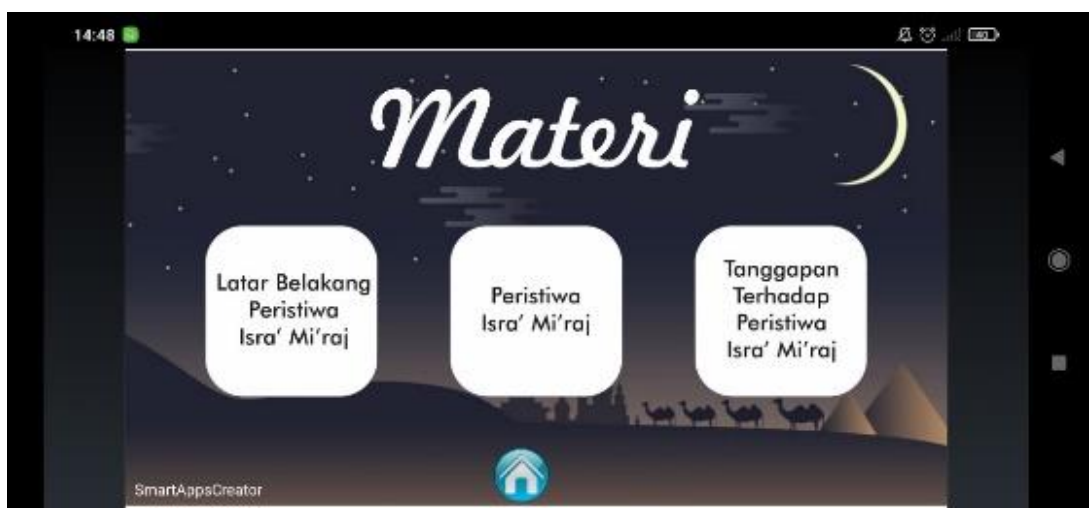

Gambar 4. Halaman materi 
Materi pembelajaran ini didalamnya disajikan peta konsep berisi materi Isra' Mi'raj. Materi pertama latar belakang, materi kedua peristiwa isra' m'raj dalam menu ini ketika dibuka akan masuk ketiga pilihan yaitu perjalanan isra', perjalalan mi'raj dan kejadian kejadian dalam isra' miraj, materi ketiga berisi tentang tanggapan tanggapan peristiwa isra' mi'raj.

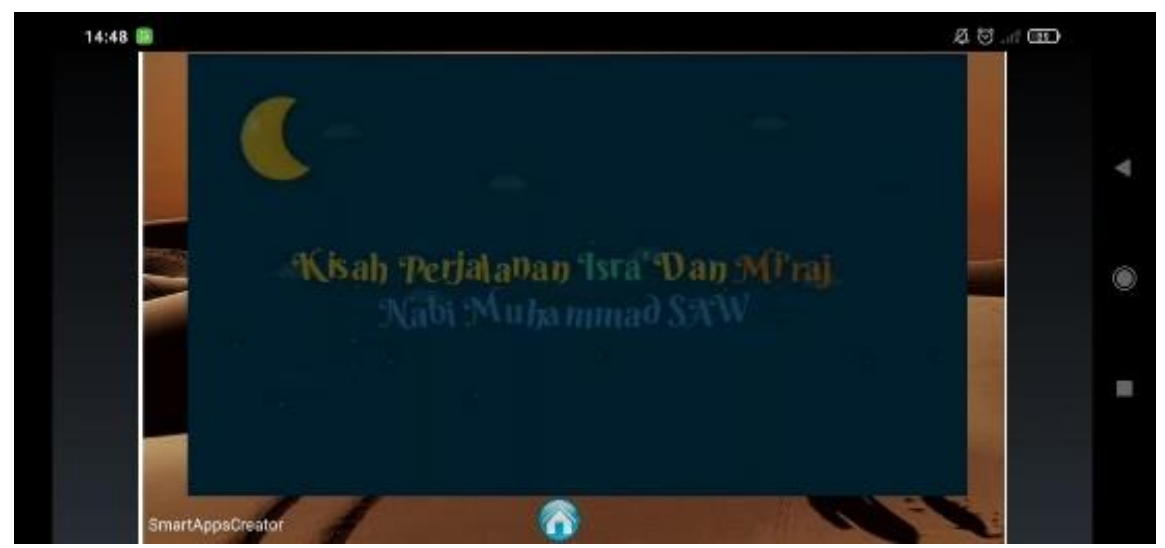

Gambar 5. Halaman Vidio

Halaman ini berisi tentang materi peristiwa isra mi'raj dan hikmahnya dalam bentuk suara dan gambar. Halaman ini bisa menjadi pilihan bagi siswa yang lebih mudah memahami pelajaran berbasis audio visual.

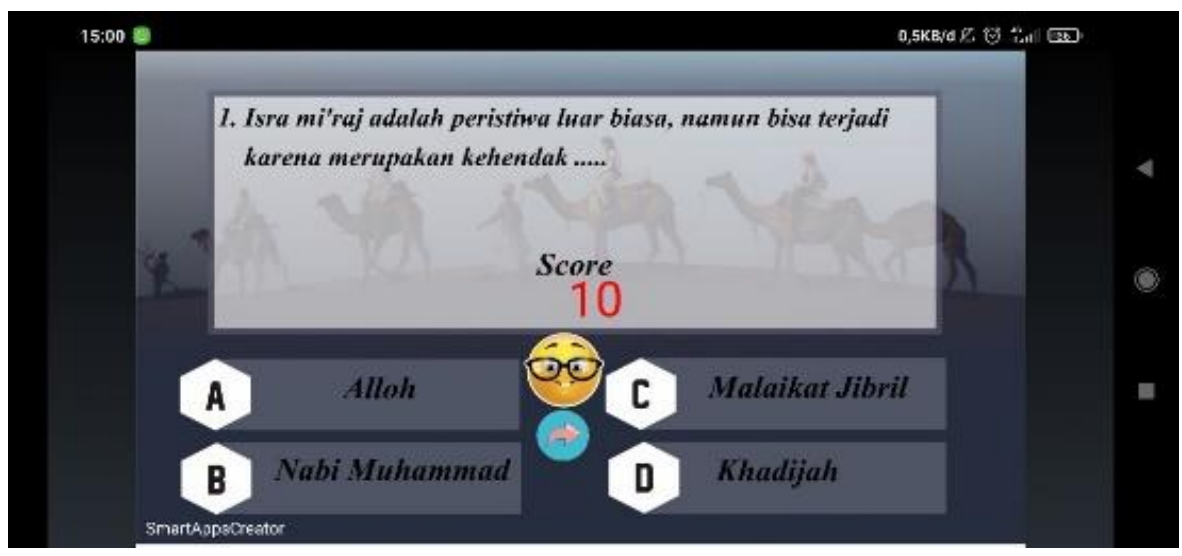

Gambar 6. Halaman kuis

Halaman ini berisi soal yang digunakan untuk mengetahui sejauh mana pengetahuan dan pemahaman siswa tentang materi isra' mi'raj. Pada halaman ini siswa langsung dapat mengetahui nilai yang diperoleh setelah mengerjakan soal sebagai bentuk feedback.

Kelayakan hasil dari pengembangan produk aplikasi android ini dapat diketahui melalui hasil belajar pre-test dan post-test berdasarkan model pengembangan 4D. 
Tahap uji hasil belajar menggunakan uji-t dengan tujuan untuk mengetahui perbedaan nilai pada aspek kognitif (pengetahuan) sebelum dan sesudah menggunakan media berbasis aplikasi android. Sedangkan validitas produk dilakukan masing-masing 3 orang ahli media dan 3 orang ahli materi. kriteria kelayakan materi dinlai berdasarkan aspek pembelajaran dan aspek materi. ${ }^{11}$

\section{Tabel 2 Validasi Penilaian Ahli Materi}

\begin{tabular}{|c|c|c|c|c|}
\hline \multirow[b]{2}{*}{ Pernyataan } & \multicolumn{4}{|c|}{ Score Penilaian } \\
\hline & $\begin{array}{c}\text { Ahli } \\
\text { materi } 1\end{array}$ & $\begin{array}{c}\text { Ahli } \\
\text { materi } 2\end{array}$ & $\begin{array}{l}\text { Ahli materi } \\
3\end{array}$ & $\begin{array}{c}\text { Score } \\
\text { Maksimal }\end{array}$ \\
\hline $\begin{array}{l}\text { Materi mencakup KI, } \\
\mathrm{KD} \text {, dan Indikator }\end{array}$ & 4 & 4 & 4 & 4 \\
\hline $\begin{array}{l}\text { Kesesuai materi dengan } \\
\text { KD }\end{array}$ & 3 & 3 & 4 & 4 \\
\hline $\begin{array}{l}\text { Materi yang disajikan } \\
\text { mendukung } \\
\text { pencapaian KD }\end{array}$ & 3 & 4 & 4 & 4 \\
\hline $\begin{array}{l}\text { Kelengkapan materi } \\
\text { sesuai indikator }\end{array}$ & 3 & 4 & 4 & 4 \\
\hline $\begin{array}{l}\text { Materi dalam media } \\
\text { sesuai indikator }\end{array}$ & 4 & 3 & 3 & 4 \\
\hline $\begin{array}{l}\text { Kemenarikan penyajian } \\
\text { materi memotivasi } \\
\text { siswa }\end{array}$ & 4 & 4 & 3 & 4 \\
\hline $\begin{array}{l}\text { Materi yang awalnya } \\
\text { sulit menjadi menarik }\end{array}$ & 4 & 3 & 3 & 4 \\
\hline $\begin{array}{l}\text { Kebebasan memilih } \\
\text { materi }\end{array}$ & 3 & 4 & 4 & 4 \\
\hline $\begin{array}{ll}\text { Program mudah } \\
\text { digunakan }\end{array}$ & 3 & 4 & 4 & 4 \\
\hline Ketepatan feedback & 3 & 4 & 4 & 4 \\
\hline $\begin{array}{l}\text { Pengguna mengatahui } \\
\text { feedback }\end{array}$ & 4 & 4 & 4 & 4 \\
\hline $\begin{array}{l}\text { Kejelasan petunjuk } \\
\text { penggunaan }\end{array}$ & 4 & 3 & 3 & 4 \\
\hline $\begin{array}{l}\text { Kejelasan penulisan } \\
\text { soal }\end{array}$ & 3 & 4 & 4 & 4 \\
\hline Tingkat kesulitan soal & 3 & 4 & 3 & 4 \\
\hline Manfaat program & 4 & 4 & 4 & 4 \\
\hline $\begin{array}{l}\text { Program } \\
\text { mempermudah siswa } \\
\text { mempelajari materi }\end{array}$ & 4 & 4 & 4 & 4 \\
\hline Jumlah & 56 & 60 & 59 & 64 \\
\hline
\end{tabular}

${ }^{11}$ Urip Purwono, Standar Penilaian Bahan Ajar, (Jakarta :BNSP, 2008) 


\begin{tabular}{|l|c|c|c|c|}
\hline \multirow{2}{*}{ Pernyataan } & \multicolumn{4}{|c|}{ Score Penilaian } \\
\cline { 2 - 5 } & $\begin{array}{c}\text { Ahli } \\
\text { materi 1 }\end{array}$ & $\begin{array}{c}\text { Ahli } \\
\text { materi 2 }\end{array}$ & $\begin{array}{c}\text { Ahli materi } \\
3\end{array}$ & $\begin{array}{c}\text { Score } \\
\text { Maksimal }\end{array}$ \\
\hline Nilai Maksimum & 64 & 64 & 64 & 64 \\
\hline $\begin{array}{l}\text { hasil Penilaian } \\
\text { kelayakan aspek } \\
\text { penyajian (\%) }\end{array}$ & $87 \%$ & $93,7 \%$ & $92,1 \%$ & $100 \%$ \\
\hline
\end{tabular}

Validasi yang telah dilakukan ketiga ahli materi terdiri dari dua aspek yaitu materi dan pembelajaran. Data yang diperoleh kemudian dianalisis dan dikonversikan sesuai tabel kelayakan materi. Hasil analisis oleh kedua ahli materi tersebut menyatakan materi pembelajaran dan instrument tes media pembelajaran aplikasi android sejarah kebudayaan Islam memiliki kriteria sangat layak dengan presentase hasil 87\%, 93,7\%. Dan $92,1 \%$

Kelayakan pada pengembangan produk media pembelajaran berbasis aplikasi android mata pelajaran sejarah kebudayaan Islam ditinjau dari segi operasi program dan tampilan. ${ }^{12}$ adapun kriteria operasi program dan tampilan meliputi aspek keluwesan dan kemudahan perpindahan halaman ke sub selanjutnya, tata letak (layout) media, kombinasi warna, kualitas gambar, kualitas video, kesesuaian dengan background, keterbacaan teks, pemilihan font serta ukuran teks dan kejelasan audio.

Tabel 3.Validasi Penilaian Ahli Media

\begin{tabular}{|l|c|c|c|c|}
\hline \multicolumn{2}{|c|}{ Pernyataan } & \multicolumn{4}{|c|}{ Score Penilaian } \\
\cline { 2 - 5 } & $\begin{array}{c}\text { Ahli media } \\
1\end{array}$ & $\begin{array}{c}\text { Ahli } \\
\text { media 2 }\end{array}$ & $\begin{array}{c}\text { Ahli } \\
\text { media 3 }\end{array}$ & $\begin{array}{c}\text { Score } \\
\text { maksimal }\end{array}$ \\
\hline $\begin{array}{l}\text { Keluwesan menentukan } \\
\text { menu }\end{array}$ & 4 & 4 & 4 & 4 \\
\hline $\begin{array}{l}\text { Kebebasan memilih menu } \\
\text { Kemudahan perpindahan } \\
\text { halaman }\end{array}$ & 3 & 4 & 4 & 4 \\
\hline $\begin{array}{l}\text { Kemudahan pemilihan dan } \\
\text { pemindahan ke sub materi } \\
\text { lain }\end{array}$ & 4 & 3 & 2 & 4 \\
\hline $\begin{array}{l}\text { Konsistensi penempatan } \\
\text { navigasi }\end{array}$ & 4 & 3 & 3 & 4 \\
\hline \begin{tabular}{l} 
Ketepatan tombol \\
\hline
\end{tabular} & 3 & 4 & 4 & 4 \\
\hline
\end{tabular}

${ }^{12}$ Munir, Multimedia \& Aplikasi dalam Pendidikan, (Bandung : Alfabeta, 2012) TADARUS: Jurnal Pendidikan Islam/Vol 10, No 1 (2021) 


\begin{tabular}{|c|c|c|c|c|}
\hline \multirow[b]{2}{*}{ Pernyataan } & \multicolumn{4}{|c|}{ Score Penilaian } \\
\hline & $\begin{array}{c}\text { Ahli media } \\
1\end{array}$ & $\begin{array}{c}\text { Ahli } \\
\text { media } 2\end{array}$ & $\begin{array}{c}\text { Ahli } \\
\text { media } 3\end{array}$ & $\begin{array}{c}\text { Score } \\
\text { maksimal }\end{array}$ \\
\hline $\begin{array}{l}\text { Kemudahan membaca } \\
\text { petunjuk teknis }\end{array}$ & 4 & 3 & 4 & 4 \\
\hline $\begin{array}{l}\text { Kemudahan pemakaian } \\
\text { program }\end{array}$ & 3 & 4 & 3 & 4 \\
\hline $\begin{array}{l}\text { Kesesuaian letak gambar } \\
\text { dan teks }\end{array}$ & 4 & 4 & 4 & 4 \\
\hline Proposional letak teks & 4 & 3 & 4 & 4 \\
\hline $\begin{array}{l}\text { Kesesuaian pemilihan jenis } \\
\text { huruf dan ukuran }\end{array}$ & 3 & 3 & 3 & 4 \\
\hline Kesesuaian warna huruf & 4 & 4 & 4 & 4 \\
\hline $\begin{array}{l}\text { Kesesuian gambar dengan } \\
\text { materi }\end{array}$ & 3 & 4 & 4 & 4 \\
\hline $\begin{array}{l}\begin{array}{l}\text { Kejelasan gambar dalam } \\
\text { materi }\end{array} \\
\end{array}$ & 3 & 3 & 2 & 4 \\
\hline $\begin{array}{l}\text { Keberadaan animasi tidak } \\
\text { mengganggu materi }\end{array}$ & 3 & 4 & 4 & 4 \\
\hline $\begin{array}{l}\text { Kesesuaian video dengan } \\
\text { materi }\end{array}$ & 4 & 3 & 4 & 4 \\
\hline $\begin{array}{l}\text { Keberadaan } \\
\text { membantu video } \\
\text { materi }\end{array}$ & 4 & 4 & 3 & 4 \\
\hline Kesesuaian proposi warna & 3 & 3 & 4 & 4 \\
\hline $\begin{array}{ll}\text { Kesesuaian } & \text { warna } \\
\text { menambah motivasi }\end{array}$ & 3 & 4 & 4 & 4 \\
\hline $\begin{array}{l}\text { Musik pengiring dapat } \\
\text { mengurangi kebosanan }\end{array}$ & 3 & 3 & 2 & 4 \\
\hline $\begin{array}{l}\text { Musik mendukun } \\
\text { penyampaian materi }\end{array}$ & 4 & 3 & 3 & 4 \\
\hline Background jelas & 4 & 4 & 3 & 4 \\
\hline $\begin{array}{l}\text { Penyajian } \\
\text { sederhana }\end{array}$ & 3 & 4 & 3 & 4 \\
\hline Jumlah & 80 & 82 & 77 & 92 \\
\hline Nilai Maksimum & 92 & 92 & 92 & 92 \\
\hline $\begin{array}{l}\text { hasil Penilaian kelayakan } \\
\text { aspek penyajian }(\%)\end{array}$ & $87,5 \%$ & $89,1 \%$ & $83,6 \%$ & $100 \%$ \\
\hline
\end{tabular}

Kelayakan penggunaan media diperoleh dari validasi ahli media yang penilaiannya dikonversikan dalam interval kelayakan media. Hasil data validasi ahli media diketahui kualitas media sangat layak digunakan dengan presentase $87,5 \%$, $89,1 \%$ dan $83,6 \%$. 
Efektivitas media berbasis aplikasi android dapat diketahui melalui hasil tes aspek kognitif (pengetahuan). Siswa diberikan pre-test dan post-test serta dillihat perbandingan hasil rata-rata menggunakan uji-t. Pada proses tes atau penilaian ini peserta didik berjumlah 27 orang A dan B 27 orang. Adapun hsil pre-test dan post-test dapat dilihat.

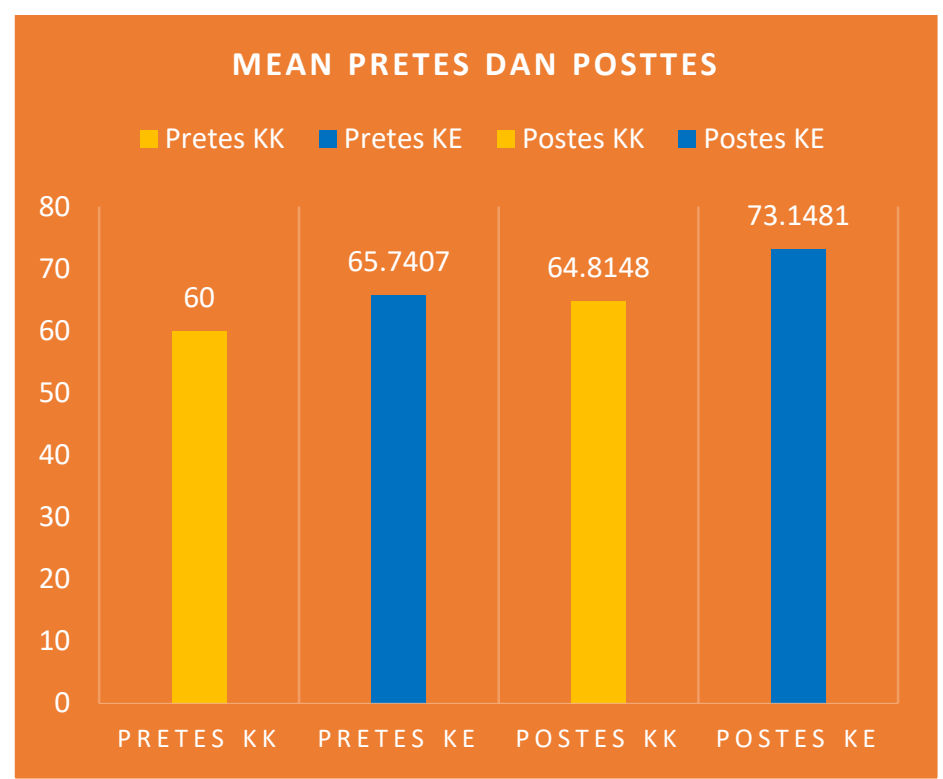

Gambar 7. Hasil rata-rata pre-test dan post-test

Dari nilai rata rata (mean) yang diperoleh, mean kelompok kontrol yang awalnya 60,000 berubah menjadi 64,8148. Sedangkan mean kelompok eksperimen yang awalnya 65,7407 berubah menjadi 73,1481 . Sehingga dapat disimpulkan bahwa mean kelompok yang menggunakan media pembelajaran berbasis aplikasi android mendapatkan kenaikan nilai yang lebih tinggi daripada kelompok yang menggunakan media konvensional. Dari ata hasil belajar peserta didik ini, menjadi rujukan pengembang untuk membuat kesimpulan bahwa media berbasis aplikasi android ini dapat memberikan kemudahan dan meningkatkan hasil belajar peserta didik.

Hal ini sejalan dengan penelitian oleh Rahmat, dkk menunjukkan bahwa mobile learning simulasi digital dikatakan sangat praktis serta memudahkan peserta didik untuk memahami pembelajaran. ${ }^{13}$ Guna mengetahui peningkatan pemahaman peserta didik maka dilakukan analisis data dari hasil soal evaluasi dengan menggunakan uji t.

\footnotetext{
${ }^{13}$ Riki Fajri Rahmat, Lativa Mursyida, Fahmi Rizal, Krismadinata Krismadinata, Yuliawati Yunus, Pengembangan Media Pembelajaran Berbasis Mobile Learning Pada Mata Pelajaran Simulasi Digita Jurnal Inovasi Teknologi Pendidikan Vol 6, No 2, 2019. 
Sebelum melakukan uji dilakukan uji normalitas untuk mengetahui distribusi kedua data tersebut. Apabila data terdistribusi normal dengan nilai sig. $>0,05$ maka dilakukan uji t dan sebaliknya jika data tidak terdistribusi normal dengan nilai sig. < 0,05 maka dilakukan uji wilcoxon.

\section{Tabel 4. Uji Normalitas Preetes}

\begin{tabular}{ccccccccc}
\hline \multicolumn{1}{c}{ Tests of Normality } \\
\cline { 1 - 7 } & \multirow{3}{*}{ KELAS } & \multicolumn{2}{c}{ Kolmogorov-Smirnov ${ }^{\mathrm{a}}$} & \multicolumn{3}{c}{ Shapiro-Wilk } \\
\cline { 3 - 8 } & & Statistic & df & Sig. & Statistic & df & Sig. \\
\hline \multirow{2}{*}{ HASIL } & Pretes_Kontrol & 132 & 27 &, $200^{*}$ &, 872 & 27 &, 003 \\
\cline { 2 - 8 } & Pretes_Eksperimen &, 112 & 27 &, $200^{*}$ &, 968 & 27 &, 556 \\
\hline
\end{tabular}

Tabel 5. Uji Normalitas postes

\begin{tabular}{llllllll}
\hline \multicolumn{10}{c}{ Tests of Normality } \\
\hline \multirow{2}{*}{ KELAS } & \multicolumn{1}{l}{ Kolmogorov-Smirnov ${ }^{\mathrm{a}}$} & \multicolumn{4}{c}{ Shapiro-Wilk } \\
\cline { 2 - 8 } & Statistic & df & Sig. & Statistic & df & Sig. \\
\hline HASIL & Posttes_Kontrol &, 137 & 27 &, $200^{*}$ &, 951 & 27 &, 223 \\
\cline { 2 - 8 } & Posttest_Eksperimen &, 097 & 27 &, $200^{*}$ &, 979 & 27 &, 845 \\
\hline
\end{tabular}

Hasil uji normalitas melalui uji Kolmogorov-Smirnov pada tabel 4 dan 5 . diketahui pada pretest dan posttest keduanya memiliki nilai sig 0,200 yang memenuhi kriteria $\alpha>0,05$. Sehingga kedua data tersebut terdistribusi dengan normal sehingga tahap selanjutnya yaitu dilakukan analisis uji t.

Uji t dilakukan untuk mengetahui apakah terdapat perbedaan signifikan secara statistik tingkat pemahaman sebelum ataupun sesudah uji coba media berbasis aplikasi andrioid.Apabila nilai sig. $<0,05$ maka terjadi peningkatan pemahaman setelah dilakukannya uji coba pada peserta didik. 


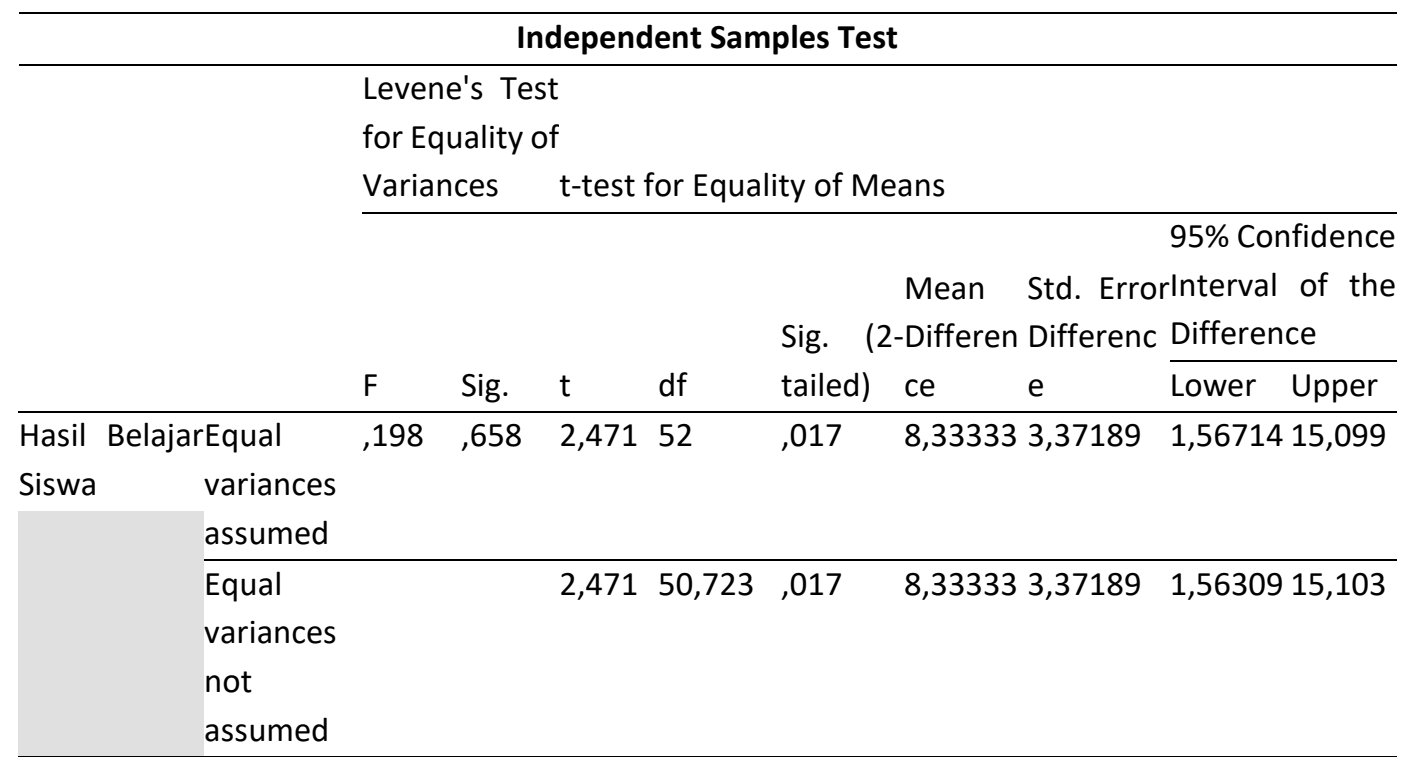

Hasil analisis uji t independent t-test terlihat bahwa Sig (2-tailed) adalah 0,017 $<0,05$ maka kedua populasi memiliki rata-rata nilai pre-test dan post-test yang berbeda.

Sejalan dengan hal tersebut penelitian yang dilakukan oleh Fitriah Nurohmah dan Imam Bukhori mengatakan media pembelajaran android dapat membantu memudahkan penyampaian materi dengan tambahan fitur kompetensi, kuis, video pembelajaran, dan glosarium yang dapat diakses secara offlline serta kemudahan pengunduhan pada web yang telah disediakan dilengkapi buku panduan penggunaannya. $^{14}$

Penelitian dan pengembangan media pembelajaran berbasis aplikasi android ini merupakan pengembangan yang bertujuan untuk membantu dan memudahkan pendidik atau guru dalam menyampaikan materi pembelajaran. Pengembangan media pembelajaran berbasis aplikasi android ini diharapkan memberi angin segar oleh peserta didik dalam menerima materi sejarah yang semula dianggap menjemukan dan sulit dipahami.

Pengembangan media pembelajaran memiliki peran penting dalam meningkatkan kualitas proses pembelajaran terutama membantu peserta didik menangkap, menerima dan memahami materi pembelajaran. Media termasuk dua unsur penting dalam proses pembelajaran selain metode.

\footnotetext{
${ }^{14}$ Fitia Nur Rohmah \& Imam Buchori, Pengembangan Media Pembelajaran Interaktif Mata Pelajaran Korespondensi Berbasis Android Menggunakan Articulate Storyline. Economic \& Education Jurnal Vol 2, No 2, 2020 
Memilih media pembelajaran hendaknya mengetahui manfaat media tersebut. Nana Sujana dan Ahmad Rivai berpendapat mengenai manfaat penggunaan media dalam proses pembelajaran peserta didik $:^{15}$

1. Menumbuhkan motivasi peserta didik

2. Membantu memudahkan peserta didik dalam memahami materi.

3. Menjadikan peserta didik lebih aktif.

Melalui pengembangan media ini kegiatan belajar mengajar berlangsung sebuah interaksi maka media memiliki peranan penting sebagai salah satu komponen dalam proses pembelajaran.

Pengembangan media berbasis aplikasi android ini dilakukan melalui beberapa tahapan dari tahap awal pendefinisian (define) sampai penyebaran (disseminate). Setelah melalui tahapan tersebut mendapatkan penilaian dari validator yaitu ahli media dan ahli materi yang kemudian dilakukan merivisi terhadap kekurangan yang terdapaat dalam media.

Adapun kelebihan media berbasis aplikasi android ini mudah diperasikan oleh pendidik dan peserta didik, tidak membutuhkan waktu lama penggunaan, tampilan media disesuaikan dengan karakteristik peserta didik kelas IV dengan variasi gambargambar terang yang dapat membuat semangat dan termotivasi belajar dan media ini berupa aplikasi yang didalamnya terdapat gambar, vidio, dan kuis sebagai evaluasi. Sedangkan yang menjadi kekurangan media ini masih terpaku pada satu bab.

Karakteristik produk media berbasis aplikasi android yang dikembangkan ini adalah produk media berupa aplikasi yang dapat dijadikan alternatif dalam memudahkan peserta didik belajar memahami dan mengingat materi. Hasil dari pengembangan media ini adalah produk media yang telah divalidasi oleh ahli, media ini layak digunakan sebagai media pembelajaran mata pelajaran sejarah kebudayaan Islam.

Acuan lain media ini layak digunakan sebagai media adalah hasil uji produk. Bahwasannya ada perbedaan hasil belajar peserta didik melalui Uji-t dan disimpulkan hasil belajar post-test kelas eksperimen lebih tinggi dari rata-rata hasil belajar kelas kontrol. Jadi, peningkatan hasil belajar peserta didik diperoleh dari penggunaan media

\footnotetext{
${ }^{15}$ Nana Sudjana dan Ahmad Rivai, Media Pengajaran. (Bandung: Sinar Baru Algensindo, 2010) TADARUS: Jurnal Pendidikan Islam/Vol 10, No 1 (2021)
} 
yang menambah ketertarikan dan motivasi peserta didik. Penggunaan media pembelajaran dengan aplikasi ini dirasa lebih baik dari pada peserta didik yang pembelajarannya konvensional.

Hal tersebut sesuai dengan salah satu fungsi media pembelajaran yaitu tidak hanya mengandung unsur artistic saja akan tetapi memudahkan siswa mempelajari materi pelajaran sehingga dapat meningkatkan gairah siswa untuk belajar. ${ }^{16}$

\section{Simpulan}

Penelitian pengembangan media berbasis aplikasi android dengan menggunakan model pengembangan 4D meliputi analisis kebutuhan pengembangan produk (pendefinisian-penyebaran), validasi, ujicoba serta produk akhir. telah menghasilkan produk media pembelajaran yang siap untuk digunakan. Kelayakan media pembelajaran berbasis aplikasi android ini telah ditinjau dari berbagai aspek diantaranya tampilan media (program) pengoperasian atau penggunaan program, isi (materi) dan aspek pembelajaran. Media pembelajaran ini mendapatkan hasil penilaian dari ahli materi, ahli media dalam kategori "sangat layak" yang artinya media layak digunakan dalam proses pembelajaran.

Respons yang diberikan oleh peserta didik terhadap media pembelajaran yang dikembangkan memperoleh hasil yang positif. Hasil uji coba yang telah dilakukan kepada peserta didik yang mana berdasarkan hasil analisis pemahaman peserta didik menunjukkan bahwa media pembelajaran mampu meningkatkan pemahaman peserta didik, walaupun masih perlu ujicoba lebih lanjut.

Adapun kelebihan media berbasis aplikasi android ini mudah diperasikan oleh pendidik dan peserta didik, tidak membutuhkan waktu lama penggunaan, tampilan media disesuaikan dengan karakteristik peserta didik kelas IV dengan variasi gambargambar terang yang dapat membuat semangat dan termotivasi belajar dan media ini berupa aplikasi yang didalamnya terdapat gambar, vidio, dan kuis sebagai evaluasi. Sedangkan yang menjadi kekurangan media ini masih terpaku pada satu bab.

\footnotetext{
16 Teni Nurita, Pengembangan Media Pembelajaran Untuk Meningkatkan Hasil Belajar Siswa dalam junal Misykat, Vol 3, No 1, 2018. 


\section{E. Saran}

Saran peneliti yaitu produk media dapat dimanfaatkan sebagai alat yang membantu pembelajaran dikelas ataupun daring agar kegiatan belajar lebih efektif dan menyenangkan. Sebaiknya dalam pengembangan media ini tidak hanya mengacu pada materi sejarah kebudayaan Islam saja bila perlu sebaiknya mencakup aspek lain.

Sebaiknya dalam pengembangan ini uji coba produk dapat dilakukan lebih beragam lagi sehingga menghasilkan suatu media pembelajaran yang baik dan dapat digunakan secara lebih luas.

\section{F. Daftar Pustaka}

Afandi, Rifki. (2015). Pengembangan Media Pembelajaran Permainan Ular Tangga untuk Meningkatkan Motivasi Belajar Siswa. Sidoarjo : JINoP (Jurnal Inovasi Pembelajaran)

Arikunto, Suharsimi. (2012). Prosedur Penelitian Suatu Pendekatan Praktik. Jakarta: Rineka Cipta.

Buchori, A. (2019). Pengembangan Multimedia Interaktif Dengan Pendekatan Kontekstual Untuk Meningkatkan Pemecahan Masalah Kemampuan Matematika. Jurnal Inovasi Teknologi Pendidikan, 6(1), 104-115.

Djamarah, Syaiful Bahri., \& Zain, Aswan. (2012). Strategi Belajar Mengajar. Jakarta:Penerbit Rinek Cipta.

Maksum, A. (2008). Metodologi Penelitian dalam Olahraga. Surabaya: FIK Unesa Press.

Munir. (2012). Multimedia dan Aplikasi dalam Pendidikan. Bandung: Alfabeta.

Nurrita, Teni. (2018) Pengembangan Media Pembelajaran Untuk Meningkatkan Hasil Belajar Siswa dalam junal Misykat, 3(1), 171

NurRohmah, F., \& Bukhori, I. (2020). Pengembangan Media Pembelajaran Interaktif Mata Pelajaran Korespondensi Berbasis Android Menggunakan

Articulate Storyline. Economic \& Education Jurnal 2(2) 171.

Purnowo, Urip. (2008). Standar Penilaian bahan Ajar. Jakarta: BNSP.

Rahmat, R. F., Mursyida, L., Rizal, F., Krismadinata, K., \& Yunus, Y. (2019). Pengembangan Media Pembelajaran Berbasis Mobile Learning Pada Mata Pelajaran Simulasi Digital. Jurnal Inovasi Teknologi Pendidikan, 6(2), 116-126.

Rusman. (2018). Belajar dan Pembelajaran Berbasis Komputer. Bandung: Alfabeta.

Sadiman, A., Rahardjo, R., Haryono, A., \& Harjito. (2009). Media Pedidikan. Jakarta: PT RajaGrafindo Persada. 
Sudjana, Nana \& Rivai, Ahmad. (2010). Media Pengajaran. Bandung: Sinar Baru Algensindo.

Sugiyono. (2011). Metode Penelitian Kuantitatif, Kualitatif dan $R \&$ D. Bandung: PT Remaja Rosdakarya.

(2015). Metode Penelitian dan Pengembangan : Research and Development. Bandung: Alfabeta. 